Rev.MVZ Córdoba 20(1):4427-4435, 2015. ISSN: 0122-0268

ORIGINAL

\title{
Non-genetic effects on growth characteristics of Brahman cattle
}

\author{
Efectos no genéticos sobre caracteres de crecimiento del ganado \\ Brahman
}

\author{
Nicacia Hernández-Hernández, ${ }^{1}$ M.Sc, Juan Martínez-González, ${ }^{1 *}$ Ph.D, \\ Gaspar Parra-Bracamonte, ${ }^{2}$ Ph.D, Martín Ibarra-Hinojosa, ${ }^{1}$ Ph.D, Florencio Briones-Encinia, ${ }^{1}$ Ph.D, \\ Pánfilo Saldaña-Campos, ${ }^{3}$ Ph.D, Eligio Ortega-Rivas, ${ }^{4}$ Ph.D.
}

\begin{abstract}
${ }^{1}$ Universidad Autónoma de Tamaulipas-Facultad de Ingeniería y Ciencias. Centro Universitario Adolfo López Mateos. Apartado Postal 149. Ciudad Victoria, Tamaulipas, México. C.P. 87149. Tel. Fax: +52 834318 1721. ${ }^{2}$ Instituto Politécnico Nacional-Centro de Biotecnología Genómica. Boulevard del Maestro SN. Esq. Elías Piña, Col. Narciso Mendoza. Reynosa, Tamaulipas, México. C.P. 88710. ${ }^{3}$ Instituto Tecnológico de Huejutla. Carretera Huejutla-Challahuiyapa km 5.5, Huejutla de los Reyes, Hidalgo, México. C.P. 43000. ${ }^{4}$ Asociación Mexicana de Criadores de Cebú. Naranjo No. 1006 Col. Águila. Tampico, Tamaulipas, México. C.P. 89230. *Correspondencia: jmartinez@uat.edu.mx
\end{abstract}

Received: June 2014; Accepted: Novenber 2014.

\begin{abstract}
Objective. To determine how some non-genetic factors influence weights at birth (BW), weaning (WW) and yearling (YW) of Brahman calves. Materials and methods. Data corresponding to 58257, 57045 and 40364 for BW, WW and YW, respectively, were analyzed. The models included the effects of year and season of birth and sex, and were considered simple interactions. Results. All effects were significant $(p<0.05)$ for BW, WW and YW. Only the season of birth didn't have a significant effect $(p>0.05)$ on WW. The average general BW, WW and YW were $32 \pm 3.2,188 \pm 37.7$ and $291 \pm 56.8 \mathrm{~kg}$, respectively. Variables evaluated that take into account the year of birth show a trend to increase weight each year. In relation to the birth season on BW and $\mathrm{YW}$, it was observed that calves born during the rainy season were heavier than those born during the dry season. Similarly, male calves were heavier than females at birth, weaning and one year of age. The effects of the analyzed interactions were significant $(p<0.05)$ for the three variables, except for the season of birth per sex interaction, which did not have a significant effect $(p>0.05)$ for BW and WW. Conclusions. The studied non-genetic factors were important and should be taken into account in management strategies when striving to increase the efficiency of the productive system.
\end{abstract}

Key words: Zebu, birth weight, weaning weight, year weight. (Source: AIMS)

\section{RESUMEN}

Objetivo. Determinar cómo influyen algunos factores no genéticos sobre los pesos al nacer (PN), al destete (PD) y al año (PA) de terneros Brahman. Materiales y métodos. Se analizaron 58257; 57045 y 40364 datos para PN, PD y PA, respectivamente. Los registros fueron de animales nacidos durante los años 1994 a 2012. El modelo incluyó los efectos de año y época de nacimiento y sexo, también se consideraron las interacciones simples. Resultados. Todos los efectos resultaron significativos $(p<0.05)$ 
para PN, PD y PA. Sólo el efecto de época de nacimiento no tuvo efecto significativo ( $>0.05)$ para el PD. Las medias generales de PN, PD y PA fueron de $32 \pm 3.2,188 \pm 37.7$ y $291 \pm 56.8 \mathrm{~kg}$, respectivamente. Para las variables evaluadas sobre el año de nacimiento se observó una tendencia de aumento del peso conforme transcurrieron los años de estudio. Con relación a la época de nacimiento sobre el PN y PA se observó que los terneros nacidos durante la época de lluviosa fueron más pesados, que los nacidos durante la época seca. De igual modo, los terneros machos fueron más pesados que las hembras al nacimiento, destete y al año de edad. Los efectos de las interacciones analizadas fueron significativas $(p<0.05)$ para las tres variables, a excepción, de la interacción época de nacimiento por sexo que no tuvo efecto significativo $(p>0.05)$ para el PN y PD. Conclusiones. Los factores no genéticos estudiados fueron importantes y deben ser tenidos en cuenta en las estrategias de manejo cuando se quiere incrementar la eficiencia del sistema productivo.

Palabras clave: Cebú, peso al nacer, peso al destete, peso al año. (Fuente: AIMS)

\section{INTRODUCTION}

Bovine growth is represented by increasing of the animal's weight during different the stages of his life. Therefore, the importance of evaluating growth is based on selecting both males and females and has a great economic importance for production systems $(1,2)$.

An important component to evaluate in order to estimate the profitability of bovine meat production is the growth of calves as well as the reproductive efficiency of the cow (3). From a productive point of view, intermediate weight at birth (WB) is the most beneficial, since high weights are associated with distocic births and very low weights are associated with an increase in the pre-weaning mortality of the calves. Thus, the WB has a positive association with the weaning weight (WW) and later growth measurements (2). On the other hand, WW influences the determination of the economic efficiency of any bovine production system and can be recommended as selection criteria (3).

A way to measure productive behavior is by evaluating growth, reproduction and survival characteristics (3). These characters are influenced by a series of environmental and genetic factors. Among environmental factors, the most common are: year of birth, season or month of birth, sex of the calf, age of the mother (measured in years or number of births), among others. It is known that these factors are different within the relative magnitude, according to agroecological area, production unit and genetic constitution of the population under study; however, it is necessary to assess the degree to which these factors affect certain characteristics in a defined population (4-6).

On the other hand, the zebu livestock has a superior capacity to regulate body temperature during heat caloric stress in comparison with

\section{INTRODUCCIÓN}

El crecimiento bovino está representado por el incremento del peso del animal en diferentes etapas de su vida. Por lo tanto, la importancia de evaluar el crecimiento radica en que es una característica de selección tanto de hembras como de machos y de alta importancia económica para los sistemas de producción $(1,2)$.

Un componente importante a evaluar para estimar la rentabilidad en la producción de carne bovina, es el crecimiento de las crías, además de la eficiencia reproductiva de la vaca (3). Desde el punto de vista productivo, un peso al nacer (PN) intermedio es más adecuado, ya que los pesos altos se asocian con partos distócicos y pesos muy bajos se asocian con incrementos en la mortalidad pre-destete de los becerros. Asimismo, el PN tiene una asociación positiva con el peso al destete (PD) y posteriores medidas de crecimiento (2). Por otra parte, el PD influye en la determinación de la eficiencia económica de cualquier sistema de producción de bovinos y puede ser recomendado como criterio de selección (3).

Una forma de medir el comportamiento productivo es mediante la evaluación de características de crecimiento, reproducción y de sobrevivencia (3). Estos caracteres están influenciados por una serie de factores de tipo ambientales y de tipo genéticos. Entre los ambientales los más comunes son: año de nacimiento, época o mes de nacimiento, sexo del becerro, edad de la madre (medida en años o número de parto), entre otros. Se sabe que estos factores son diferentes en la magnitud relativa, según la zona agroecológica, unidad de producción y constitución genética de la población en estudio; sin embargo, es necesario valorar el grado con el cual estos factores afectan cierta característica en una determinada población (4-6). 
European livestock (7). This superior capacity to regulate body temperature is the result of lower metabolic rates and a greater capacity to lose heat. In the same way, it has been demonstrated that in zebu breeds there exists an important variation that resists tick infestations (8).

The objective of the present study was to evaluate the influence of some environmental factors on the growth of Brahman calves.

\section{MATERIALS AND METHODS}

Data base. The study was done with data of weights of calves in the Ponderal Development Control Program authorized by the Mexican Association of Zebu Breeders (AMCC for its initials in Spanish) with headquarters in Tampico, Tamaulipas, Mexico (9). The animals were weighed at least every 90 days from birth until approximately 550 days old (10).

The information analyzed corresponded to 58257 Brahmans born between 1994 and 2012 and registered with AMCC. The ranches where the animals were were spread out through the whole country, mainly in the tropical areas of Mexico. Modifying the feeding and handling systems; but in general registered breeders handle the animals uniformly (10); the handling of these animals has been previously described by several authors $(2,11)$.

Growth variables considered in this study were weight at birth (WB $=58257)$, weight at weaning $(W W=57045)$ and yearling weight $(Y W=40364)$. To analyze the data base, incomplete records were eliminated and the WW and YW were adjusted according to the recommendations of the Beef Improvement Federation of the United States (12).

Statistic model and analysis. Data was submitted to a variance analysis using the MIXED procedure from the SAS statistical packet (13) that included the random effect of the bull, and the fixed effect of the birth year (BY) and sex (SX). The birth seasons were defined as: $1=$ dry (January to June) and $2=$ rainy (July to December). By preliminary analysis the ranch effect and the age of the mother were discarded from the final analysis.

The model described was:

$Y_{i j k l m}=\mu+T_{i}+A N_{j}+E N_{k}+S E_{i}+(A N * E N)_{j k}+(A N * S E)$ ${ }_{\mathrm{jl}}+(\mathrm{EN} * \mathrm{SE})_{\mathrm{kl}}+\mathrm{E}_{\mathrm{ijk} k \mathrm{~m}}$

Where:

$Y_{i j k l m}=$ Is weight (at birth; at weaning; at one year) $\mu=$ General average of weight (at birth or
Por otro lado, el ganado cebú posee una capacidad superior de regular la temperatura corporal durante el estrés calórico en comparación con el ganado europeo (7). Esta capacidad superior para la regulación de la temperatura corporal es el resultado de menores tasas metabólicas y de una mayor capacidad de perder calor. Igualmente, se ha demostrado que en las razas cebuinas existe una variación importante en la resistencia a las infestaciones de garrapata (8).

El objetivo del presente trabajo fue evaluar la influencia de algunos factores ambientales sobre el crecimiento terneros de la raza Brahman.

\section{MATERIALES Y MÉTODOS}

Base de datos. El estudio fue realizado con datos de pesajes de los terneros en el Programa de Control de Desarrollo Ponderal, avalados por la Asociación Mexicana de Criadores de Cebú (AMCC) con sede en Tampico, Tamaulipas, México (9). Los animales fueron pesados al menos cada 90 días, desde el nacimiento hasta aproximadamente los 550 días de edad (10).

La información analizada correspondió a 58257 animales Brahman nacidos entre los años 1994 y 2012; y registrados ante la AMCC. Los hatos donde se encontraban los animales estaban distribuidos en todo el país, principalmente en las regiones tropicales de México. Modificando los sistemas de alimentación y manejo; pero en general los ganaderos de registro manejan de manera uniforme sus animales (10), el manejo de estos animales ha sido descrito previamente por diversos autores $(2,11)$.

Las variables de crecimiento consideradas en este estudio fueron el peso al nacimiento $(P N=58257)$, peso al destete $(P D=57045)$ y peso al año $(P A=40364)$. Para analizar la base de datos se eliminaron los registros incompletos de los animales y las variables PD y PA se ajustaron de acuerdo con las recomendaciones de la Federación de Mejoramiento de Ganado de Carne de Estados Unidos (12).

Modelo y análisis estadístico. Los datos fueron sometidos a un análisis de varianza utilizando el procedimiento MIXED del paquete estadístico SAS (13), que incluyó el efecto aleatorio del toro, y el efecto fijo de año de nacimiento (AN), época de nacimiento (EN) y sexo (SX). Las épocas de nacimiento fueron definidas como: $1=$ seca

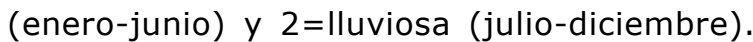
Por análisis preliminares fueron descartadas del análisis final el efecto de hato y la edad de la madre. 
weaning)

$T_{i}=$ Random effect of the $i$-th bull.

$A N_{i}=$ Fixed effect of the $j$-th year of birth

$\mathrm{EN}_{\mathrm{k}}=$ Fixed effect of the $\mathrm{k}$-th birth season

$\mathrm{SE}_{1}=$ Fixed effect of the I-th sex of the animal

$(A N * E N)_{j k}=$ Effect of the interaction year of birth $x$ birth season

$(A N * S E)_{j 1}=$ Effect of the interaction year of birth

$X$ sex

$(\mathrm{EN} * \mathrm{SE})_{\mathrm{kl}}=$ Effect of the interaction birth season

$X$ sex

$\mathrm{E}_{\mathrm{ijklm}}=$ Experimental error.

To determine different statistical differences, the Tukey measurement comparison test with a significance level of $5 \%$ was used.

\section{RESULTS}

The average general weight for BW was $32.0 \pm 3.2$ $\mathrm{kg}$, with a variation coefficient of $8.2 \%$. For this parameter all the variation sources had a significant effect $(p<0.05)$.

The measurement found for weaning weight was $188.0 \pm 37.7 \mathrm{~kg}$, with a variation coefficient of $16.4 \%$. On the other hand, all the effects were significant $(p<0.05)$ with the exception of birth season.

Lastly, the general measurement $\pm D E$ for the weight at one year was $290.9 \pm 56.8 \mathrm{~kg}$. For this parameter, all the variation sources also had a significant effect $(p<0.05)$.

\section{DISCUSSION}

Weight at birth. The average birth weight was $32.0 \pm 3.2 \mathrm{~kg}$. This result is similar to what was reported in other investigations $(4,5,11,14)$ where it is mentioned that the BW was around $32.0 \mathrm{~kg}$. On the other hand, Cienfuegos-Rivas et al (15) reported an average of $37.7 \pm 6.1 \mathrm{~kg}$.

Table 1 shows the measurements of BW for BY. It can be seen that the calves born in 1996 had a lower weight at $31.3 \pm 3.1 \mathrm{~kg}$, while calves born in 2005 were the heaviest, reaching an average of $33.1 \pm 3.5 \mathrm{~kg}$. Several authors $(4,5,11,14)$ mention that the BY affects the BW significantly. These differences in weight can be attributed to changes in the availability of forage and management of different herds, as well as climatic variations from year to year given the increasingly more erratic precipitation.

In the same way, calves born during the rainy season weighed an average of $200 \mathrm{~g}$ more than those born during the dry season (Table 2 ). These
El modelo descrito fue:

$\mathrm{Y}_{\mathrm{ijklm}}=\mu+\mathrm{T}_{\mathrm{i}}+\mathrm{AN}_{\mathrm{j}}+\mathrm{EN}_{\mathrm{k}}+\mathrm{SE}_{\mathrm{l}}+(\mathrm{AN} * \mathrm{EN})_{\mathrm{jk}}+(\mathrm{AN} * \mathrm{SE})$

${ }_{j l}+(E N * S E)_{k l}+E_{i j k l m}$

Donde:

$\mathrm{Y}_{\mathrm{ijklm}}=$ Es el peso (al nacer; al destete; al año)

$\mu=$ Media general del peso (al nacer o al destete)

$T_{i}=$ Efecto aleatorio del i-ésimo toro

$A^{\prime} N_{j}=$ Efecto fijo del j-ésimo año de nacimiento

$\mathrm{EN}_{\mathrm{k}}=$ =Efecto fijo de la k-ésima época de nacimiento

$\mathrm{SE}_{1}=$ Efecto fijo del l-ésimo sexo del animal

$(A N * E N)_{j k}=$ Efecto de la interacción año de nacimiento $x$ época de nacimiento

$(A N * S E)_{j 1}=$ Efecto de la interacción año de nacimiento $x$ sexo

$(E N * S E)_{k 1}=$ Efecto de la interacción época de nacimiento $x$ sexo

$E_{i j k l m}=$ Error experimental.

Para determinar las diferencias estadísticas significativas, se aplicó la prueba de comparación de medias de Tukey con un nivel de significancia del $5 \%$.

\section{RESULTADOS}

El peso promedio general para el PN fue de $32.0 \pm 3.2 \mathrm{~kg}$, con un coeficiente de variación de $8.2 \%$. Para este parámetro todas las fuentes de variación tuvieron efecto significativo $(p<0.05)$.

La media hallada para el peso al destete fue de $188.0 \pm 37.7 \mathrm{~kg}$, con un coeficiente de variación de $16.4 \%$. Por otra parte, todos los efectos resultaron significativos $(p<0.05)$, excepto la época de nacimiento.

Por último, la media general \pm DE para peso al año fue de $290.9 \pm 56.8 \mathrm{~kg}$. Para este parámetro todas las fuentes de variación tambien tuvieron efecto significativo $(p<0.05)$.

\section{DISCUSIóN}

Peso al nacer. El peso promedio para PN fue de $32.0 \pm 3.2 \mathrm{~kg}$. Este resultado es similar a lo reportado en otras investigaciones $(4,5,11,14)$ donde se menciona que el PN estaba alrededor de los $32.0 \mathrm{~kg}$. Por otra parte, Cienfuegos-Rivas et al (15) reportaron un promedio de $37.7 \pm 6.1 \mathrm{~kg}$.

En la tabla 1 se muestran las medias de PN por AN. Se puede apreciar que los terneros nacidos en el año de 1996 presentaron los pesos menores con $31.3 \pm 3.1 \mathrm{~kg}$, mientras que los terneros que nacieron en el año 2005 resultaron los más pesados alcanzando una media de $33.1 \pm 3.5$ $\mathrm{kg}$. Diversos autores $(4,5,11,14)$, mencionaron 
Table 1. Averages $\pm D E$ of weight at birth, weaning and yearlings for Brahman calves by birth year.

\begin{tabular}{|c|c|c|c|c|c|c|c|c|c|c|c|c|}
\hline \multirow{3}{*}{$\begin{array}{c}\text { Date of Birth } \\
1994\end{array}$} & \multicolumn{4}{|c|}{ Weight at birth (kg) } & \multicolumn{4}{|c|}{ Weight at weaning $(\mathrm{kg})$} & \multicolumn{4}{|c|}{ Weight at a year old $(\mathrm{kg})$} \\
\hline & \multirow{2}{*}{$\frac{\mathbf{N}}{359}$} & \multicolumn{2}{|c|}{ Average $\pm \mathrm{DE}$} & \multirow[b]{2}{*}{$\mathrm{g}$} & \multirow{2}{*}{$\frac{\mathbf{N}}{362}$} & \multicolumn{2}{|c|}{ Average $\pm \mathrm{DE}$} & \multirow[b]{2}{*}{$\mathrm{L}$} & \multirow{2}{*}{$\begin{array}{c}\mathbf{N} \\
359\end{array}$} & \multicolumn{2}{|c|}{ Average $\pm \mathrm{DE}$} & \multirow[b]{2}{*}{$\mathrm{k}$} \\
\hline & & 31.5 & 2.5 & & & 163.5 & 28.0 & & & 213.9 & 42.7 & \\
\hline 1995 & 605 & 31.4 & 3.2 & $\mathrm{~g}$ & 619 & 175.3 & 33.1 & $\mathrm{~J}$ & 605 & 229.3 & 52.3 & $\mathrm{j}$ \\
\hline 1996 & 761 & 31.3 & 3.1 & $\mathrm{~g}$ & 828 & 170.1 & 32.2 & $\mathrm{~K}$ & 761 & 240.1 & 51.0 & $\mathrm{i}$ \\
\hline 1997 & 1708 & 31.5 & 3.1 & $\mathrm{~g}$ & 1596 & 177.0 & 34.4 & $\mathrm{ij}$ & 1708 & 244.7 & 57.8 & $\mathrm{i}$ \\
\hline 1998 & 3117 & 32.1 & 3.7 & $\mathrm{f}$ & 2478 & 179.9 & 34.8 & hi & 3117 & 257.7 & 61.0 & $\mathrm{~h}$ \\
\hline 1999 & 3522 & 32.1 & 3.0 & ef & 3086 & 181.4 & 36.4 & hi & 3522 & 262.4 & 62.8 & $\mathrm{~h}$ \\
\hline 2000 & 3426 & 32.4 & 1.7 & cdef & 3098 & 182.5 & 39.9 & $\mathrm{gh}$ & 3425 & 276.5 & 63.6 & $\mathrm{~g}$ \\
\hline 2001 & 4349 & 32.6 & 1.5 & abcdef & 4182 & 188.6 & 37.6 & de & 4349 & 283.5 & 62.4 & $\mathrm{f}$ \\
\hline 2002 & 4691 & 32.9 & 2.2 & $a b c$ & 4483 & 194.7 & 37.6 & $a b$ & 4690 & 289.0 & 61.9 & cdef \\
\hline 2003 & 4802 & 32.8 & 2.7 & abcd & 4885 & 187.9 & 41.6 & def & 4801 & 285.5 & 63.2 & ef \\
\hline 2004 & 5030 & 32.9 & 3.4 & $a b$ & 4844 & 190.6 & 36.7 & $\mathrm{~cd}$ & 5030 & 289.0 & 57.6 & cdef \\
\hline 2005 & 4857 & 33.1 & 3.5 & a & 4871 & 190.7 & 36.8 & $\mathrm{~cd}$ & 4856 & 291.9 & 55.9 & bcde \\
\hline 2006 & 4623 & 32.8 & 3.6 & $a b c$ & 4724 & 189.1 & 40.3 & de & 4621 & 288.8 & 59.1 & cdef \\
\hline 2007 & 4190 & 32.6 & 3.5 & abcdef & 4297 & 187.9 & 37.1 & def & 4190 & 288.5 & 53.9 & def \\
\hline 2008 & 4069 & 32.5 & 3.5 & bcdef & 4043 & 187.2 & 36.3 & ef & 4065 & 292.7 & 52.2 & bcde \\
\hline 2009 & 3673 & 32.7 & 3.6 & abcde & 3762 & 193.9 & 34.1 & $a b$ & 3673 & 298.5 & 48.9 & b \\
\hline 2010 & 3267 & 33.0 & 4.5 & $a b$ & 3384 & 192.7 & 34.8 & $\mathrm{bc}$ & 3267 & 296.5 & 51.9 & $\mathrm{bc}$ \\
\hline 2011 & 1145 & 32.8 & 3.1 & abcd & 1350 & 196.7 & 38.4 & A & 1145 & 293.4 & 57.3 & bcd \\
\hline 2012 & 21 & 32.3 & 2.5 & def & 85 & 185.2 & 40.2 & $\mathrm{fg}$ & 21 & 307.7 & 32.6 & $a$ \\
\hline
\end{tabular}

abcdef averages with different literals are different (Tukey, $P=0.05$ ).

results are similar to those obtained by PeredaSolís et al (16), who showed $31.0 \mathrm{~kg}$ in the dry season and $32.0 \mathrm{~kg}$ for the rainy season. As to be expected, environmental conditions during the rainy season presented a more favorable panorama for cows, providing greater availability of enviorement the quantity and quality of forage that also translates into a greater weight in calves at birth.

Similar results were observed for the sex of the calf; in this study the males were larger than the females by $1.8 \mathrm{~kg}$ (Table 2). These results are similar to those obtained by Stüve et al (4) and Pereda-Solís et al (16). This difference in weight is attributed to androgenic hormones, particularly testosterone.

On the other hand, the effects of BY $x$ BS and BY $x$ SX were significant $(p<0.05)$. With relation to the interaction of BY and BS it was observed that calves born in 2010 in the rainy season were heaviest with $33.6 \mathrm{~kg}$, while those born in 1997 in the rainy season were only $31.8 \mathrm{~kg}$. These results do not agree with those reported by Stüve et al (4). que el AN afectó de manera significativa el PN. Estas diferencias de peso se pueden atribuir a los cambios en la disponibilidad de forraje y de manejo en los distintos rebaños, así como a las variaciones climáticas entre los años dado que cada vez son más erráticas las precipitaciones.

De igual modo, los terneros nacidos durante la época lluviosa pesaron en promedio $200 \mathrm{~g}$ más que los nacidos durante la época seca (Tabla 2). Estos resultados son similares a los obtenidos por Pereda-Solís et al (16) quienes observaron para la época seca $31.0 \mathrm{~kg}$ y para la época lluviosa $32.0 \mathrm{~kg}$. Como es de suponerse las condiciones ambientales durante la época de lluvias presentan un panorama más favorable para las vacas, al haber una mayor disponibilidad de forraje en cuanto a cantidad y calidad que también se traduce en un mejor peso en los terneros al nacimiento.

Resultados similares se observaron para el sexo del ternero, en este estudio los machos superaron a las hembras en $1.8 \mathrm{~kg}$ (Tabla 2). Estos resultados son similares a los obtenidos por Stüve et al (4) y Pereda-Solís et al (16). Esta diferencia de peso se le 
Tabla 2. Averages $\pm D E$ of weight at birth, weaning and yearlings in Brahman calves by season of birth and sex.

\begin{tabular}{|c|c|c|c|c|c|c|}
\hline \multirow{2}{*}{$\begin{array}{l}\text { Season } \\
\text { of Birth }\end{array}$} & \multicolumn{2}{|c|}{$\begin{array}{c}\text { Birth } \\
\text { weight (kg) }\end{array}$} & \multicolumn{2}{|c|}{$\begin{array}{c}\text { Weaning } \\
\text { Weight (kg) }\end{array}$} & \multicolumn{2}{|c|}{$\begin{array}{c}\text { Weight at } \\
\text { one year }(\mathbf{k g})\end{array}$} \\
\hline & $\mathbf{N}$ & $\begin{array}{c}\text { Average } \\
\text { DE }\end{array}$ & $\mathbf{N}$ & $\begin{array}{c}\text { Average } \pm \\
\text { DE }\end{array}$ & $\mathbf{N}$ & $\underset{\mathrm{DE}}{\text { Average }} \pm$ \\
\hline Rainy & 25424 & $\begin{array}{c}32.7 \pm \\
3.1^{\mathrm{a}}\end{array}$ & 25639 & $\begin{array}{c}187.8 \pm \\
37.1\end{array}$ & 25418 & $\begin{array}{c}288.3^{ \pm} \\
58.8^{\mathrm{a}}\end{array}$ \\
\hline Dry & 32791 & $\begin{array}{l}32.5 \pm \\
3.3^{b}\end{array}$ & 31338 & $\begin{array}{c}188.2 \pm \\
38.1\end{array}$ & 32787 & $\begin{array}{c}278.6^{ \pm} \\
60.7^{\mathrm{b}}\end{array}$ \\
\hline \multicolumn{7}{|l|}{ Sex } \\
\hline Male & 42927 & $\begin{array}{c}33.1 \pm \\
3.2^{\mathrm{a}}\end{array}$ & 41389 & $\begin{array}{c}193.3 \pm \\
37.2^{\mathrm{a}}\end{array}$ & 42927 & $\begin{array}{c}296.8 \pm \\
56.3^{\mathrm{a}}\end{array}$ \\
\hline Female & 15288 & $\begin{array}{c}31.3^{ \pm} \\
2.9^{\mathrm{b}}\end{array}$ & 15588 & $\begin{array}{c}173.9 \pm \\
35.1\end{array}$ & 15278 & $\begin{array}{c}243.5^{ \pm} \\
52.3^{\mathrm{b}}\end{array}$ \\
\hline
\end{tabular}

$a b$ averages with different literals are different (Tukey, $p=0.05$ ).

Similarly, with the interaction of BY and SX it is observed that males born in 2005 were the heaviest with $33.1 \mathrm{~kg}$ and the females born in 1995 only reached $30.0 \mathrm{~kg}$. This effect is probably due to the weight differences between sexes over the years (16).

Weight at weaning. The general average $\pm D E$ for weight at weaning (WW) corrected at 205 days was $188.0 \pm 37.7 \mathrm{~kg}$. These results agree with those reported in literature $(6,11,14)$. However, Plasse et al (17) found a WW of 147.1 \pm 1.0 . On the other hand, Montes et al (18) reported a WW of $237.08 \mathrm{~kg}$ in Brahman cattle.

Table 1 shows averages of WW and BY and it can be appreciated that calves born in 1994 only had an average of $163.5 \pm 28.0 \mathrm{~kg}$, while those born during 2011 reached $196.7 \pm 38.4 \mathrm{~kg}$, the tendency was to increase the WW as the years of the study passed (2). These results could be due to the fact that the genetic improvement of the Brahman herds is added to the agroecological conditions of production units, which translates into greater weight of the animals $(2,16)$.

For the effect of season of birth no significant differences $(p>0.05)$ were found between the dry and rainy season (Table 2 ). These results differ from those obtained by Stüve et al (4), who observed differences in weaning weight according to the birth month.

Regarding sex, it was observed that the male calves were larger with an average of $193.3 \pm 34.0$ $\mathrm{kg}$ in comparison to the females whose average was $173.9 \pm 92.0 \mathrm{~kg}$ with a difference of 19.4 $\mathrm{kg}$ (Table 2). These results are similar to those indicated by Rodríguez et al (6) with $203.8 \mathrm{~kg}$ for males, with females at $189.6 \mathrm{~kg}$. On the other hand, Plasse et al (17) highlighted lower weight for a Brahman farm (147.0 kg). atribuye a las hormonas androgénicas, en particular a la testosterona.

Por otro lado, los efectos de las interacciones AN $x$ EN y AN x SX fueron significativas $(p<0.05)$. Con relación a la interacción de $A N$ por EN se observó que los becerros nacidos en el año 2010 y época lluviosa fueron los más pesados con 33.6 kg, mientras que los nacidos en el año 1997 en la época lluviosa solo alcanzaron los $31.8 \mathrm{~kg}$. Estos resultados no concuerdan a los reportados por Stüve et al (4).

De igual modo, para la interacción de AN por SX se observó que los machos nacidos en el año 2005 fueron los más pesados con $33.1 \mathrm{~kg}$ y las hembras nacidas en el 1995 sólo alcanzaron los $30.0 \mathrm{~kg}$. Este efecto se debe probablemente a las diferencias de peso entre sexos a través de los años (16).

Peso al destete. La media general $\pm D E$ para peso al destete (PD) corregido a los 205 días fue de $188.0 \pm 37.7 \mathrm{~kg}$. Estos resultados concuerdan con los reportados en la literatura $(6,11,14)$. Sin embargo, Plasse et al (17) encontraron un PD de 147.1 \pm 1.0 . Por otra parte, Montes et al (18) reportaron un PD $237.08 \mathrm{~kg}$ en bovinos de raza Brahman.

En la tabla 1 se observan las medias de PD por AN y se puede apreciar que los terneros nacidos en el año 1994 sólo promediaron $163.5 \pm 28.0 \mathrm{~kg}$, mientras que los nacidos durante el año 2011 alcanzaron $196.7 \pm 38.4 \mathrm{~kg}$, la tendencia fue a aumentar el PD conforme transcurrieron los años de estudio (2). Estos resultados pudieron deberse a que aunado al mejoramiento genético de las poblaciones de Brahman, también se han modificado las condiciones agroecológicas en las unidades de producción que se traducen en mejores pesos de los animales $(2,16)$.

Para el efecto de época de nacimiento no se encontraron diferencias significativas ( $p>0.05)$ entre la época seca y lluviosa (Tabla 2). Estos resultados difieren a los obtenidos por Stüve et al (4) quienes observaron diferencias en el peso al destete, debidos al mes de nacimiento.

Con relación al sexo, se observó que los terneros machos fueron superiores con una media $193.3 \pm 34.0 \mathrm{~kg}$ respecto a las hembras cuya media fue de $173.9 \pm 92.0 \mathrm{~kg}$ con una diferencia de 19.4 $\mathrm{kg}$ (Tabla 2). Estos resultados son similares a los señalados por Rodríguez et al (6) con $203.8 \mathrm{~kg}$ para los machos y las hembras de $189.6 \mathrm{~kg}$. Por otra parte, Plasse et al (17) se señalan pesos inferiores para un hato de ganado Brahman $(147.0 \mathrm{~kg})$. 
In the year of birth and seasons of birth interaction, it was observed that calves born in 2011 and the rainy season were the heaviest at $197.1 \pm 39.9 \mathrm{~kg}$, while those born in 1994 in rainy season only reached $160.3 \pm 27.8 \mathrm{~kg}$. The results agree with those of Rodríguez et al (6) and Plasse et al (17), who explained that the variation in weights is due to the changes in environmental conditions.

The interaction of year of birth and sex of the animal showed that males born in 2002 in the dry season were heavier at $200.0 \pm 35.6 \mathrm{~kg}$, and females born in 2002 in the rainy season only reached $156.6 \pm 28.4 \mathrm{~kg}$. Other investigators (6) did find differences in the interaction.

Weight by year. Lastly, the general average $\pm D E$ for weight at one year was $290.9 \pm 56.8 \mathrm{~kg}$. These results agree with those cited in literature $(2,11)$, for example in bovines of the Sardo Negro the YW was $281.4 \pm 50.1 \mathrm{~kg}$ (19). In the same way, Parra-Bracamonte et al (2) obtained a general average of $261.6 \pm 57.4 \mathrm{~kg}$. On the other hand, Velásquez and Álvarez (20) obtained lower results at $237.5 \mathrm{~kg}$.

With relation to the YB it can be observed that calves born during 1994 were lighter $(213.9 \pm 42.7 \mathrm{~kg})$, while calves born in 2012 were heaviest $(307.7 \pm 32.6 \mathrm{~kg})$. At any rate, in all the evaluated variables a tendency to increase in YW in each successive study year was observed (Table 1).

As for the seasons, calves born during the rainy season were the heaviest $(288.3 \pm 58.8 \mathrm{~kg})$, compared to those born during the dry season $(278.6 \pm 60.7 \mathrm{~kg})($ Table 2$)$. These results agree with those obtained by Pereda-Solís et al (16), who found in the rainy season an average of $(232.0 \pm 3.9 \mathrm{~kg})$ and in the dry season an average of $(225.0 \pm 12.8) \mathrm{kg}$. This could be due to adverse climatic conditions and the lack of availability to the quality and quantity of forage during the latter period.

As in BW and WW, male calves were heavier with an average of $296.8 \pm 56.3 \mathrm{~kg}$ when compared to females with an average of $243.5 \pm 52.3 \mathrm{~kg}$ with a difference of $53.3 \mathrm{~kg}$ (Table 2). These results are different from those obtained by Pereda-Solís et al $(16)$ for males $(232.0 \pm 3.9 \mathrm{~kg})$ and females $(208.0 \pm 3.1 \mathrm{~kg})$.

Similar to BW and WW, in this study the effects of simple interactions were evaluated, observing that these were significant $(p<0.05)$. In the interaction between year of birth and season of birth, it was observed that calves born in 2012
En la interacción año de nacimiento por época de nacimiento, se observó que los becerros nacidos en el año 2011 y época lluviosa fueron los más pesados con $197.1 \pm 39.9 \mathrm{~kg}$, mientras que los nacidos en el año 1994 en época lluviosa sólo alcanzaron los $160.3 \pm 27.8 \mathrm{~kg}$. Los resultados concuerdan con los de Rodríguez et al (6) y Plasse et al (17) quienes explicaron que la variación en los pesos se debía a los cambios en las condiciones ambientales.

La interacción año de nacimiento por el sexo del animal, se observó que los machos nacidos en el año 2002 en la época seca fueron los más pesados con $200.0 \pm 35.6 \mathrm{~kg}$ y las hembras nacidas en el 2002 en la época lluviosa sólo alcanzaron los $156.6 \pm 28.4 \mathrm{~kg}$. Otros investigadores (6) si encontraron diferencias con la interacción.

Peso al año. Por último, la media general $\pm D E$ para peso al año fue de $290.9 \pm 56.8 \mathrm{~kg}$. Estos resultados concuerdan con los citados en la literatura $(2,11)$, por ejemplo en bovinos de la raza Sardo Negro el PA fue $281.4 \pm 50.1 \mathrm{~kg}$ (19). De la misma manera, Parra-Bracamonte et al (2) obtuvieron un promedio general de $261.6 \pm 57.4 \mathrm{~kg}$. Por otra parte Velásquez y Álvarez, (20) obtuvieron resultados inferiores de $237.5 \mathrm{~kg}$.

Con relación al AN se pudo observar que los terneros nacidos durante el año 1994 fueron los más livianos $(213.9 \pm 42.7 \mathrm{~kg})$, mientras que los terneros que nacieron en el año de 2012 resultaron ser los más pesados $(307.7 \pm 32.6 \mathrm{~kg})$, de igual modo en las otras variables evaluadas se observa una tendencia a aumentar el PA conforme transcurrieron los años de estudio (Tabla 1).

Con relación a las épocas, los terneros nacidos durante la época lluviosa fueron los más pesados $(288.3 \pm 58.8 \mathrm{~kg})$, respecto a los nacidos en época seca $(278.6 \pm 60,7 \mathrm{~kg}$ )(Tabla 2). Estos resultados concuerdan con los obtenidos por Pereda-Solís et al (16) quienes encontraron en la época lluviosa un promedio de $(232.0 \pm 3.9 \mathrm{~kg})$ y para la época seca un promedio de $(225.0 \pm 12.8) \mathrm{kg}$. Esto puede deberse a las condiciones climáticas adversas y a la baja disponibilidad tanto en calidad como en cantidad forrajera durante el último período.

Al igual que el PN y PD, los terneros machos fueron superiores con una media $296.8 \pm 56.3 \mathrm{~kg}$ con respecto al promedio de las hembras que fue de $243.5 \pm 52.3 \mathrm{~kg}$ con una diferencia de $53.3 \mathrm{~kg}$ (Tabla 2). Estos resultados difieren a los obtenidos por Pereda-Solís et al (16) para machos (232.0 33.9 $\mathrm{kg})$ y para las hembras $(208.0 \pm 3.1 \mathrm{~kg})$.

Similar al PN y PD, en este trabajo se evaluaron los efectos de las interacciones simples, observándose que todas fueron significativas $(p<0.05)$. En la interacción año de nacimiento por época de 
in the dry season were the heaviest with 307.7 $\mathrm{kg}$, while those born in 2004 in the dry season only reached $279.7 \mathrm{~kg}$.

Accordingly, the interaction year of birth and animal sex, it was observed that males born in 2012 were the heaviest at $325.7 \mathrm{~kg}$ and females born in 2002 only reached $233.3 \mathrm{~kg}$.

Similarly, the interaction between season of birth and sex of the animal significantly affect $(p<0.05)$ calves born in the rainy season were the heaviest at $305.5 \mathrm{~kg}$, while females born in dry season were only $249.5 \mathrm{~kg}$. These results agree with Pereda-Solís et al (16), who observed that males born in the rainy season reached a greater weight $(232.0 \mathrm{~kg})$ compared to females born in the dry season $(206.0 \mathrm{~kg})$.

On the other hand, in a study to determine the effects of young Brahman yearling bulls (grey or red) on age, it was observed that the Red Brahman bulls were heavier with significant differences (20).

In conclusion, the factors of year of birth and sex significantly affect BW, WW, and YW and therefore are important to be kept in mind for handling strategies when increasing the efficiency of the productive system.

\section{Acknowledgements}

The authors wish to express their appreciation to the Mexican Association of Zebu Breeders for the facilities used during the study and the National Council for Science and Technology for the scholarship given to the first author to carry out master's studies in sciences. nacimiento, se observó que los becerros nacidos en el año 2012 y época seca fueron los más pesados con $307.7 \mathrm{~kg}$, mientras que los nacidos en el 2004 en la época seca sólo alcanzaron los $279.7 \mathrm{~kg}$.

De igual modo, en la interacción año de nacimiento por el sexo del animal, se observó que los machos nacidos en el año 2012 fueron los más pesados con $325.7 \mathrm{~kg}$ y las hembras nacidas en el 2002 sólo alcanzaron los $233.3 \mathrm{~kg}$.

De forma Similar, la interacción época de nacimiento por el sexo del animal, afectó significativamente $(p<0.05)$ los becerros nacidos en la época de lluvia fueron los más pesados con $305.5 \mathrm{~kg}$, mientras que las hembras nacidas en época seca sólo alcanzaron $249.5 \mathrm{~kg}$. Estos resultados concuerdan con PeredaSolís et al (16), quienes observaron que los machos nacidos en época lluviosa alcanzaron un peso mayor $(232.0 \mathrm{~kg}$ ) con respecto a las hembras nacidas en época seca $(206.0 \mathrm{~kg})$.

Por otro lado, es un estudio para determinar el efecto del grupo racial de los toretes Brahman (gris o rojo) sobre el año de edad, se observó que los toretes Brahman Rojo tuvieron mayor peso con diferencias altamente significativas (20).

En conclusión los factores de año de nacimiento y sexo afectan significativamente el PN, PD y PA por lo tanto, son importantes para ser tenidos en cuenta en las estrategias de manejo cuando se quiere incrementar la eficiencia del sistema productivo.

\section{Agradecimientos}

Los autores desean expresar su agradecimiento a la Asociación Mexicana de Criadores de Cebú por las facilidades prestadas para la realización del presente trabajo y al Consejo Nacional de Ciencia y Tecnología por la beca otorgada al primer autor para realizar estudios de maestría en ciencias.

\section{REFERENCES}

1. Arias M, Romero BR, Camaripano L, Arriaga L. Parámetros genéticos y no genéticos para caracteres de crecimiento en un rebaño brahman registrado. Rev Fac Cien Vet 2013; 54(2):78-88.

2. Parra-Bracamonte GM, Martínez-González JC, García-Esquivel FJ, González-Reyna A, BrionesEncinia F, Cienfuegos-Rivas EG. Tendencias genéticas y fenotípicas de características de crecimiento en el ganado Brahman de registro de México. Rev Cien FCV-LUZ 2007; 17(3):262-267.
3. Martínez G, Bustamante J, Palacios J, Montaño $M$. Efectos raciales y de heterosis materna Criolla-Guzerat para crecimiento posdestete y características de la canal. Tec Pec Mex 2006; 44(1):107-118.

4. Stüve $D$, Colmenares $O$, Birbe $B$, Herrera $P$, Martínez $N$. Factores genéticos y ambientales que afectan el peso al nacer en un rebaño de bovinos de carne. Rev Unellez Cie Tec 2001; (Volumen Especial):139-145. 
5. Rodríguez Y, Martínez GG, Galíndez RG. Factores no genéticos que afectan el peso al nacer en vacunos Brahmán registrados. Zoot Trop 2009; 27(2):163-173.

6. Rodríguez Y, Martínez GG, Galíndez RG. Factores no genéticos que afectan el peso al destete en vacunos Brahmán registrados. Zoot Trop 2009; 27(4): 383-391.

7. Hansen PJ. Physiological and celular adaptations of zebu cattle to termal stress. Anim Reprod Sci 2004; 82-83:349-360.

8. da Silva AM, de Alencar MM, de Almeida RLC, de Sena OMC, Barioni JW. Artificial infestation of Boophilus microplus in beef cattle heifers of four genetic groups. Genet Mol Res 2007; 30(4):1150-1155.

9. AMCC. Reglamento de Exposiciones [en línea] [fecha de acceso junio 01 de 2014]. URL disponible en: http://www.cebumexico.com/home/ reglamentos/ReglamentoExposiciones.pdf

10. AMCC. Reglamento Técnico del Control de Desarrollo Ponderal [en línea] 1996 [fecha de acceso junio 05 de 2014]. URL disponible en: http://www.cebumexico.com/reglamentos/ ReglamentoCDP.pdf

11. Estrada-León RJ, Magaña-Monforte JG, SeguraCorrea JC. Estimation of genetic parameters for preweaning growth traits of Brahman cattle in Southeastern Mexico. Trop Anim Health Prod 2014; 46(5):771-776.

12. Beef Improvement Federation [editorial]. Guidelines For Uniform Beef Improvement Programs. $8^{\circ}$ Edition. EEUU: The University of Georgia; 2002.

13. SAS. Version 9.12 para windows. User's quide Statistics. Statistical Analysis System Institute. SAS Institute Inc., Cary, NC; 2004.
14. Martínez GJC, Lucero MFA, Castillo RSP, Ortega RE. Estimación de algunos parámetros genéticos de crecimiento en la raza Guzerat en México. Zoot Trop 2009; 27(1):49-55.

15. Cienfuegos Rivas $E$, De Orúe Ríos M, Briones Luengo M, Martínez Gonzales J. Estimación del comportamiento productivo y parámetros genéticos de características predestete en bovinos de carne (Bos taurus) y sus cruzas, VIII Región, Chile. Arch Med Vet 2006; 38(1):69-75.

16. Pereda-Solís ME, González-Muñoz SS, ArjonaSuárez E, Bueno-Aguilar G, Mendoza-Martínez D. Ajuste de modelos de crecimiento y cálculo de requerimientos nutricionales para bovinos Brahman en Tamaulipas, México. Agrociencia 2005; 39(1):19-27.

17. Plasse D, Fossi H, Hoogesteijn R, Verde $O$, Rodríguez MC, Rodríguez R. Producción de vacas $\mathrm{F} 1$ Bos taurus $\times$ Brahman apareadas con toros Brahman y de vacas Brahman con toros F1 Bos taurus x Brahman versus Brahman. 1 . Pesos al nacer, destete, 18 meses y peso final. Liv Res Rural Dev 2000; 12(4). URL Disponible en: http://www.Irrd.org//rrd12/4/plas124a.htm

18. Montes VD, Vergara GO, Prieto ME, Rodríguez $P$. Estimación de los parámetros genéticos para el peso al nacer $y$ al destete en ganado bovino de la raza Brahman. Rev MVZ Córdoba 2008; 13(1):1184-1191.

19. Martínez-González JC, Castillo-Rodriguez SP, Lucero- Magana FA, Ortega-Rivas E. Influencias ambientales y heredabilidad para características de crecimiento en ganado Sardo Negro en México. Zoot Trop 2007; 25(1):1-7.

20. Velásquez MJC, Álvarez LAF. Relación de medidas bovinométricas y de composición corporal in vivo con el peso de la canal en novillos Brahman en el valle del Sinú. Acta Agron 2004; 53(3):61-68. 